\title{
Motif Pelaksanaan Corporate Sosial Responsibility Perusahaan (Studi Kasus: CSR PT. Holcim Indonesia Tbk. Cilacap Plant dan CSR Delegation Europian Union to Malaysia)
}

\author{
Adhianty Nurjanah ${ }^{1}$ dan Frizki Yulianti*2 \\ 1,2Universitas Muhammadiyah Yogyakarta \\ Email: adhianty@umy.ac.id, frizkiyulianti@umy.ac.id* \\ *corresponding author
}

\author{
Keywords: \\ Motive \\ Corporate Social Responsibility \\ (CSR) \\ Company
}

\begin{abstract}
The existence of various stakeholder factors and stronger social responsibility will be needed and applied in the business. The concept of social responsibility or Corporate Social Responsibility (CSR) is an important part to do. The purpose of this study was to find out the motive for implementing CSR companies in two countries, namely PT Holcim Indonesia Tbk Cilacap Indonesia Plant and the European Union Delegation to Malaysia. This research method uses case study methods and belongs to the type of qualitative descriptive research.

The results show that PT Holcim Indonesia Tbk's motives for the Cilacap Indonesia Plant and the European Union Delegation to Malaysia in implementing CSR programs are a manifestation of socially responsible business practices (Social Responsibility Business Practices) and community contributions. This is done by providing recognition in community development activities (community development) through capacity building as training and mentoring for those who receive benefits in the fields of education, health and the environment and assistance in the economic / MSME fields in this field. creating visibility and increasing the positive image of the company and stakeholders.
\end{abstract}

\begin{abstract}
ABSTRAK
Adanya berbagai tuntutan stakeholder dan semakin meningkatnya kesadaran perusahaan akan keharusan bertanggungjawab secara sosial dan berlaku etis dalam menjalankan bisnisnya maka konsep tanggung jawab sosial perusahaan atau Corporate Social Responsibility (CSR) menjadi bagian penting yang harus dilakukan. Tujuan penelitian ini untuk mengetahui motif pelaksanaan CSR perusahaan di dua negara yaitu PT Holcim Indonesia Tbk Cilacap Plant Indonesia dan Delegation of the European Union to Malaysia. Metode penelitian ini menggunakan metode studi kasus dan termasuk kedalam jenis penelitian deskriptif kualitatif.

Hasil penelitian menunjukkan bahwa motif PT Holcim Indonesia Tbk Cilacap Plant Indonesia dan Delegation of the European Union to Malaysia dalam melaksanakan program CSR adalah bentuk perwujudan dari praktek bisnis yang bertanggung jawab sosial (Socially Responsibility Bussiness Practices) dan sebagai komitmen bisnis atas usaha bisnis yang dilakukannya untuk berkontribusi mewujudkan kesejahteraan masyarakat. Hal ini dilakukan dengan cara memberikan dukungan dalam kegiatan pengembangan masyarakat (community development) melalui capacity building berupa pemberian pelatihan dan pendampingan pada masyarakat penerima manfaat di bidang pendidikan, kesehatan dan lingkungan serta pemberian bantuan modal usaha di bidang ekonomi / UMKM sebagai upaya mewujudkan kesejahteraan masyarakat serta menciptakan visibilitas dan meningkatkan reputasi positif perusahaan di mata stakeholdernya.
\end{abstract}

Copyright (C) 2018 Channel Jurnal Komunikasi. All right reserved. 


\section{PENDAHULUAN}

Adanya berbagai tuntutan dan semakin meningkatnya kesadaran perusahaan terkait dengan keharusan untuk bertanggungjawab secara sosial dan berlaku etis dalam menjalankan bisnisnya maka konsep tanggung jawab sosial perusahaan atau Corporate Social Responsibility (CSR) menjadi bagian yang tidak terpisahkan dengan kelangsungan hidup perusahaan di masa yang akan datang. Perusahaan bisnis tidak dapat dipisahkan dari lingkungan tempat perusahaan tersebut beroperasi. Berkembangnya kesadaran positif bahwa perusahaan yang berorientasi bisnis memiliki tanggung jawab terhadap berbagai stakeholdersnya mendorong perusahaan melaksanakan tanggung jawab sosialnya melalui program Corporate Social Responsibility (CSR).

Menurut Kotler dan Lee (2005) bahwa Corporate Social Responsibility (CSR) merupakan suatu komitmen perusahaan untuk meningkatkan kesejahteraan masyarakat sebagai pertimbangan dari praktek bisnis dan bentuk kontribusi dari sumber daya perusahaan. Inti dari pengertian tersebut tidak mengacu pada aktivitas bisnis yang diatur oleh peraturan perundang-undangan yang berlaku namun lebih pada komitmen kerelawanan perusahaan sehingga dipilih dan dimplementasikan dalam praktek bisnisnya. Dengan kata lain, Corporate Social Responsibility (CSR) saat ini telah menjadi cermin pembangunan sosial dalam masyarakat yang demokratis, sehingga Corporate Social Responsibility (CSR) merupakan upaya perusahaan untuk membantu pemerintah meningkatkan pertumbuhan ekonomi dan sosial dengan pendekatan yang seimbang sehingga dapat menjadi alat perusahaan untuk mencapai kesejahteraan bagi seluruh masyarakat.

Di Indonesia berdasarkan UU Perseroan Terbatas pasal 74 yang memuat aturan tentang tanggung jawab sosial dan lingkungan berimplikasi bahwa perusahaan bisnis wajib melakukan CSR. Selain itu, sesuai Undang-Undang Penanaman Modal No. 25 tahun 2007 pasal 15 dan 34 disebutkan bahwa perusahaan yang tidak melaksanakan CSR akan dikenakan sanksi administratif berupa peringatan tertulis, pembatalan kegiatan usaha, pembekuan kegiatan usaha, bahkan pencabutan izin kegiatan usaha. Selain itu bagi perusahaan BUMN (Badan Usaha Milik Negara), terdapat Peraturan Menteri Negara BUMN No. PER-05/MBU/2007 tanggal 27 April 2007, dimana perusahaan BUMN wajib menyisihkan dana untuk program kemitraan sebesar $2 \%$ dari keuntungan bersih perusahaan dan 2\% pula untuk Program Bina Lingkungan. Meskipun di Indonesia sudah terdapat UU yang menjadi dasar regulasi pelaksanaan program CSR, tetapi masing-masing perusahaan memiliki motif yang berbeda dalam melaksanakan program CSR.

The World Business Council for Sustainable Development menyatakan bahwa CSR harus berkomitmen untuk bersikap etis dan berkontribusi terhadap pembangunan ekonomi masyarakat namun tetap meningkatkan kesejahteraan pekerja dan keluarganya dan juga komunitas dan masyarakat setempat (Tencati, Perrni and Pogutz, 2004 : 175 ). Sedangkan Ife (2002) menyatakan bahwa Corporate Social Responsibility (CSR) adalah konsep moral dan etis yang berciri umum sehingga pada tataran praktisnya harus dialirkan ke dalam program-program yang konkret. Salah satu bentuk aktualisasi Corporate Social Responsibility (CSR) yaitu pemberdayaan masyarakat (Community Development). Selanjutnya Ife (2002) menyatakan bahwa pemberdayaan masyarakat (Community Development) untuk lingkungan industri pada dasarnya dapat digunakan sebagai media peningkatan komitmen masyarakat untuk dapat hidup berdampingan secara simbiotik dengan entitas bisnis (perusahaan) beserta operasinya. Dengan demikian, diharapkan program pemberdayaan masyarakat (Community Development) mampu memberikan manfaat bagi eksistensi perusahaan dan dapat digunakan untuk membangun hubungan harmonis antara perusahaan dengan masyarakat sekitar perusahaan.

Namun demikian, di Indonesia bentuk program Corporate Social Responsibility (CSR) sebagian besar hanya memberikan dukungan dana secara sukarela (voluntary), bermotif kedermawanan (philantrophy), belum berupa kegiatan pemberdayaan masyarakat (Community Development). Selain itu pelaksanaan program CSR belum memikirkan sasaran agar mau merubah perilakunya (pengetahuan, ketrampilan dan sikap) sehingga masyarakat mampu berdaya menolong dirinya sendiri. Dalam hal ini, program Corporate Social Responsibility (CSR) perusahaan hanya memberikan bantuan material atau bantuan langsung tunai kepada sasaran tanpa didukung proses pemberdayaan masyarakat melalui penyuluhan, bimbingan atau pelatihan sehingga masyarakat dapat mandiri. Bantuan yang diberikan perusahaan berupa modal, fasilitas pendidikan, kesehatan, keagamaan dan sebagainya masih bersifat top down dan kurang memperhatikan aspirasi masyarakat. Dengan demikian banyak program Corporate Social Responsibility (CSR) perusahaan yang tidak tercapai keberlanjutan (sustainability) programnya. (Sholeh, 2010). Selain itu, perusahaan masih belum menganggap bahwa CSR merupakan investasi sosial bagi perusahaan sehingga program CSR perlu menjadi bagian dari etika bisnis mereka. (Joseph, 2009 : 406).

Berdasarkan latar belakang diatas peneliti ingin mengetahui bagaimana motif perusahaan dalam melaksanakan program CSR di dua negara yaitu Indonesia dan Malaysia. Hal ini dikarenakan terdapat motif perusahaan yang berbedabeda dalam melaksanakan CSR. Ada yang melaksanakan CSR dengan motif phylantrophy / kedermawanan, atau berCSR hanya melaksanakan peraturan saja karena CSR merupakan hal yang sifatnya mandatory. Selain itu terdapat juga motif perusahaan dalam melaksanakan CSR bermotif ekonomi yang tujuan akhirnya adalah untuk meningkatkan laba perusahaan. Adapun motif CSR perusahaan yang lebih ideal adalah tidak hanya bersifat untuk mencari keuntungan saja (profit), ataupun phylantrophy bahkan mandatory saja melainkan melaksanakan CSR sebagai bentuk praktek bisnis yang bertanggung jawab sosial (Socially Responsibility Bussiness Practices) untuk berkontribusi mewujudkan kesejahteraan 
masyarakat. Adapun pemilihan kedua negara tersebut dikarenakan adanya persamaan karakteristik masyarakat dimana unsur masyarakat menjadi hal penting yang harus diperhatikan dalam pelaksanaan program CSR.

\section{METODE PENELITIAN}

Penelitian ini merupakan jenis penelitian kualitatif. Metode penelitian yang digunakan adalah metode studi kasus yang akan menyoroti berbagai faktor yang mengatur komunikasi, menggambarkan keunikannya sekaligus memberikan pemahaman mendalam mengenai kasus yang akan diamati.Tehnik pengumpulan data menggunakan data primer yakni wawancara kepada informan terkait yang dipilih secara purposive demi memenuhi kebutuhan penelitian, sedangkan data sekunder yakni menggunakan teknik studi pustaka dan dokumentasi guna mengkonfirmasi dan memperkuat data untuk dianalisis.

Dalam penelitian ini informan yang telah dipilih yakni Deni Nuryandain selaku Corporate Communication Regional 2 dan Kusdhiarta selaku Community Relations Manager PT Holcim Indonesia Tbk Cilacap Plant dan Dzul Affandi Matnoor selaku Press and Information Officer dari Delegation of the European Union to Malaysia. Data dalam penelitian ini akan dianalisis secara kualitatif. Penelitian kualitatif merupakan suatu prosedur yang menghasilkan data deskriptif berupa kata tertulis, atau lisan orang-orang atau perilaku yang diamati (Moleong, 2003: 103). Analisis data yang bersifat kualitatif mengharuskan peneliti untuk melakukan aktivitas secara serempak dengan pengumpulan data, interpretasi data dan menulis laporan penelitian (Creswell, 2012: 145). Data yang diperoleh dianalisis menggunakan model analisis interaktif (Creswell, 2012). Dengan demikian analisis data tidak dilakukan secara terpisah dengan pengumpulan data, tetapi merupakan kegiatan yang dilakukan bersama-sama. Selama pengumpulan data, peneliti bergerak secara interaktif dalam 3 komponen analisis yaitu reduksi data, sajian data dan simpulan akhir/verifikasi (Sutopo, 2006: 186). Menurut Miles dan Huberman (1984) model analisis interaktif adalah model analisis yang terdiri dari tiga komponen yaitu reduksi datam sajian data, dan penarikan kesimpulan.

Analisis interaktif dilakukan dengan mengkomparasikan setiap data atau kelompok data yang telah berhasil dikumpulkan oleh peneliti untuk menemukan persamaan atau perbedaan dan keterkaitannya. Selanjutnya setelah data diatur dalam kelompok berdasarkan variabel atau faktornya juga selalu dikomparasikan untuk menemukan beragam kesimpulan. Kesimpulan yang ditemukan ketika belum mantap akan dilakukan verifikasi oleh peneliti yaitu dengan kembali ke lapangan untuk mengumpulkan data terfokus dengan tujuan untuk lebih mendukung pemantapan kesimpulan penelitian yang dihasilkan. Proses analisis data dimulai dengan menelaah seluruh jenis data yang tersedia, yakni dari wawancara mendalam, observasi, focus group of discussion (fgd), dokumen, dokumentasi foto dan sebagainya.

Pada saat peneliti menyusun catatan lapangan mengenai berbagai hal yang berkaitan dengan motif pelaksanaan program CSR pada PT Holcim Indonesia Tbk Cilacap Plant Indonesia dan Delegation of the European Union to Malaysia secara lengkap, reduksi data segera dilakukan dan diteruskan dengan bentuk sajian data yang bersifat sementara. Setelah itu peneliti mulai membuat kesimpulan sementara, karena proses pengumpulan data masih berlangsung. Pengumpulan data dan analisisnya berjalan bersamaan sehingga proses analisis terjadi secara interaktif dan menguji antar komponen yang secara keseluruhan bersifat siklus dan berlangsung terus-menerus dalam waktu cukup lama. Dengan menggunakan teknik analisis tersebut maka hasil kesimpulan mengenai motif pelaksanaan program CSR pada PT Holcim Indonesia Tbk Cilacap Plant Indonesia dan Delegation of the European Union to Malaysia dapat teruji secara akurat.

Proses reduksi data dilakukan peneliti dengan jalan menyeleksi, memfokuskan serta menyederhanakan catatan lapangan yang didapat dari pengumpulan data. Setelah peneliti membaca, mempelajari, menelaah maka langkah peneliti selanjutnya adalah mengadakan reduksi data yang dilakukan dengan cara membuat abstraksi dan menyusunnya dalam satuan-satuan berdasarkan masalah-masalahnya. Abstraksi pada langkah ini peneliti berusaha membuat rangkuman yang mencakup proses dan penyataan-pernyataan yang ada. Selanjunya kemudian peneliti menyusunnya dalam satuan-satuan unit yang berfungsi untuk menentukan kategori. Satuan dalam penelitian ini dapat berwujud kalimat faktual, maupun kalimat ungkapan berwujud paragraf penuh. Satuan-satuan tersebut diberi code berupa penandaan sumber asal satuan seperti catatan lapangan, dokumen, laporan, penandaan nama informan, penandaan waktu dan cara penumpulan data serta penandaan lokasi.

Hasil reduksi data kemudian disajikan dalam bentuk catatan/narasi yang memungkinkan simpulan penelitian dapat dilakukan. Simpulan-simpulan yang sudah ada diperkuat terus menerus sampai dengan akhir penelitian. Pemantapan perlu dilakukan dengan mengulang aktivitas reduksi data, sajian data dan kembali memperbaiki simpulan yang dirasa kurang.

\section{HASIL DAN ANALISIS}

\section{a. Definisi Corporate Social Responsibility (CSR)}

Definisi Corporate Social Responsibility (CSR) menurut The World Business Council for Sustainable Development (dalam Chand, 2006) adalah: "CSR is the continuing commitment by business to behave ethically and contribute to economic development while improving the quality of life of the workforce and their families as well as of the local community and society at large". CSR dapat pula didefinisikan sebagai: "voluntary firm actions designed to improve social 
or environmental conditions (Aguilera et al., 2007; Mackey at al., 2007) merupakan tindakan volunteer (kemauan sendiri) tanpa paksaan dari pihak manapun, termasuk didalamnya kewajiban yang diharuskan oleh pemerintah yang sifatnya mandatory, serta penekananan bahwa CSR adalah sebuah komitmen bisnis perusahaan yang bertujuan dimaksudkan untuk meningkatkan kondisi sosial dan lingkungan. Berdasarkan definisi tersebut dapat disimpulkan bahwa perusahaan dalam menjalankan operasi bisnisnya juga harus berkontribusi dan memiliki kepedulian terhadap kualitas kehidupan pada masyarakat luas, lingkungan, agar dapat meningkatkan kesejahteraan bagi masyarakat secara luas. Bahwa CSR adalah tanggung jawab manajemen yaitu untuk memberikan kontribusi bagi kesejahteraan masyarakat. CSR dianggap sebagai kewajiban yang berada di luar hukum dan ekonomi untuk mendapatkan tujuan jangka panjang yang menguntungkan bagi masyarakat. The World Business Council for Sustainable Development (WBCSD:2000) dalam Rudito (2013:7) mendefinisikan tentang CSR sebagai berikut: "CSR is the continuing commitment by business to behave ethically and contributed to economic development while improving the quality of live of the workforce and their families as well as of the local community and society at large". Definisi tersebut mengungkapkan bahwa CSR adalah komitmen bisnis untuk berkontribusi dalam pembangunan ekonomi berkelanjutan, bekerja dengan para karyawan perusahaan, keluarga karyawan berikut komunitas lokal dan masyarakat secara keseluruhan dalam rangka meningkatkan kualitas kehidupan.

\section{b. Motif Perusahaan Melaksanakan Corporate Social Responsibility(CSR)}

Kotler dan Lee (2005) mengidentifikasi enam (6) pilihan program bagi perusahaan untuk melakukan inisiatif dan aktivitas yang berkaitan dengan berbagai masalah sosial sekaligus sebagai wujud komitmen dari tanggung jawab sosial perusahaan. Keenam pilihan sebagai motif perusahaan melakukan CSR, yaitu:

\section{Cause Promotions (Promosi Kegiatan Sosial)}

Bentuk Cause Promotions merupakan bentuk komitmen perusahaan dengan memberikan kontribusi dana atau model penggalaan dana dengan tujuan meningkatkan kesadaran akan masalah-masalah sosial tertentu.

2. Cause-Related Marketing (Pemasaran terkait kegiatan sosial)

Perusahaan menyisihkan sepersekian persen dari pendapatan perusahaan sebagai bentuk kontribusi

perusahaan bagi maslah sosial tertentu untuk periode atau jenis produk tertentu. Bentuk ini dengan kata lain merupakan donasi perusahaan sebagai wujud komitmen perusahaan.

3. Corporate Social Marketing (Pemasaran kemasyarakatan perusahaan) Perusahaan membantu pengembangan maupun implementasi dari kegiatan kampanye dengan tujuan fokus unruk merubah perilaku tertentu yang bisa berdampak negatif.

4. Corporate Philantrophy (Kegiatan Filantropi perusahaan)

Perusahaan berinisiatif dengan memberikan secara langsung kontribusi dalam bentuk donasi atau sumbangan tunai kepada suatu kegiatan amal.

5. Community Volunteering (Pekerja sosial kemasyarakatan secara sukarela)

Komitmen yang dilakukan perusahaan berupa aktivitas memberikan bantuan dan mendorong karyawan serta mitra bisnisnya untuk secara sukarela terlibat membantu masyarakat setempat.

6. Socially Responsibility Bussness Practices (Praktik bisnis yang memiliki tanggung jawab sosial) Memberikan dukungan dalam pengembangan masyarakat yang disesuaikan dengan usaha atau kegiatan bisnis masyarakat.

\section{c. Tipologi Perusahaan dalam menerapkan CSR}

Untuk melihat bagaimana perusahaan dalam menerapkan CSR terdapat 3 (tiga) Tipologi perusahaan yang dapat dikelompokkan menjadi Perusahaan Nakal, Perusahaan Licik, Perusahaan Baik, dan Perusahaan Maju.

Dua tipe perusahaan pertama responnya cenderung masih negatif, yakni melawan atau menyembunyikan. Seiring dengan meningkatnya kesadaran pihak internal perusahaan dan tekanan pihak eksternal (publik, media masa, stakeholders). Tipe perusahaan baik dan perusahaan maju merespon CSR. Sedangkan perusahaan nakal cenderung tidak melaksanakan apa-apa atau hanya melakukan CSR yang bersifat karikatif. Sedangkan perusahaan maju melakukan CSR berdasarkan kaidah-kaidah Community Development dan bahkan melesat jauh dengan menerapkan prinsip- prinsip investasi sosial (Suharto. 2010).

Tabel 1. Tipologi Perusahaan Dalam Menerapkan CSR

\begin{tabular}{|l|l|l|}
\hline \multicolumn{1}{|c|}{ TIPE PERUSAHAAN } & \multicolumn{1}{c|}{ RESPON } & \multicolumn{1}{c|}{ SPEKTRUM PENDEKATAN } \\
\hline Perusahaan Nakal & Melawan & Zero to charity (hit and run) \\
\hline Perusahaan Licik & Menyembunyikan & Charity of Philantrohy (kiss and run) \\
\hline Perusahaan Baik & Menyesuaikan & Community relations to community development \\
\hline Perusahaan Maju & Mengembangkan & Community development to social investment \\
\hline
\end{tabular}

Sumber: CSR \& Comdev Investasi Kreatif Perusahaan Di Era Globalisasi.

Suharto. E. 2010 


\section{d. Deskripsi Pelaksanaan Program CSR PT. Holcim Indonesia Tbk Cilacap Plant}

Program CSR di Indonesia tertuang dalam regulasi salah satunya melalui Undang-Undang Nomor 40 Tahun 2007 tentang Perseroan Terbatas Pasal 74 yang menyebutkan bahwa diwajibkan bagi setiap perusahaan yang menjalankan usahanya di bidang atau berkaitan dengan sumber daya alam untuk melaksanakan tanggung jawab sosial dan lingkungan atau di masyarakat yang disebut sebagai Corporate Social Responsibility (CSR) atau tanggung jawab sosial perusahaan. Selain itu regulasi pemerintah tentang CSR juga tertuang dalam Peraturan Pemerintah (PP) Nomor 47 Tahun 2012 yaitu tentang tanggung jawab sosial dan lingkungan (TJSL) perseroan terbatas yang merupakan pelaksanaan pasal 74 UU 40 / 2007 tentang perseroan terbatas.

Peraturan Pemerintah (PP) ini menyebutkan bahwa tanggung jawab sosial dan lingkungan (TJSL) merupakan kewajiban bagi perusahaan yang menjalankan kegiatan usahanya di bidang sumber daya alam (SDA) atau di bidang yang berkaitan dengan SDA, misalnya perusahaan pertambangan atau perkebunan. Kewajiban itu dituangkan dalam rencana kerja tahunan perusahaan yang memuat rencana kegiatan dan anggaran yang dibutuhkan untuk pelaksanaan TJSL serta dilaporkan dalam laporan tahunan perusahaan. Perusahaan yang memiliki kewajiban TJSL akan dikenakan sanksi bila tidak melaksanakan kewajibannya, tetapi sebaliknya dapat diberikan penghargaan oleh instansi yang berwenang bila telah berperan dan melaksanakan tanggung jawab sosial dan lingkungan (TJSL).

Program CSR yang diregulasikan oleh pemerintah melalui Peraturan Perundang-Undangan direspon positif oleh PT. Holcim Indonesia Tbk Cilacap Plant. Hal ini terbukti bahwa dalam menjalankan operasinya Program CSR sudah menjadi kewajiban dan komitmen bisnis bagi PT. Holcim Indonesia Tbk Pabrik Cilacap, yang berpedoman kepada azas kebermanfaatan untuk mewujudkan masyarakat sejahtera dan mandiri. Adapun dasar pelaksanaan program CSR, PT. Holcim Indonesia Tbk, mengacu pada buku Panduan Pemberdayaan Masyarakat PT. Holcim Indonesia Tbk yang berisi: Kebijakan CSR PT. Holcim Indonesia Tbk, didalamnya memuat 6 (enam) Pilar yaitu Etika Bisnis, Praktek Ketenagakerjaan, Kesehatan dan Keselamatan Kerja, Keterlibatan Masyarakat, Hubungan dengan Pelanggan dan Supplier serta Pengawasan Kerja. PT. Holcim Indonesia Tbk Cilacap Plant memiliki dasar kebijakan tersendiri dalam pelaksanan program CSR perusahannya. Seperti yang disampaikan oleh Bapak Kusdhiarto berikut ini:

"Bagi Holcim, CSR adalah komitmen bisnis dan dibangun diatas enam (6) pilar yang sejalan dengan kebijakan pemerintah yaitu: (1). CSR berarti melaksanakan kewajiban kode etik bisnis, (2) CSR merupakan kebijakan ketenagakerjaan, 3). Keselamatan dan kesehatan kerja, 4). Dalam menjalankan CSR harus ada peran serta masyarakat, 5). Hubungan pelanggan dan penyalur dan yang terakhir adalah pemantauan dan pelaporan kinerja”.

(Wawancara, Bapak Kusdiharto GA \& ComRel Manager di Kantor PT. Holcim Tbk Cilacap Plant tanggal 2 Juni 2018).

Dalam menjalankan kegiatan tanggung jawab sosial perusahaan (CSR) PT. Holcim Indonesia Tbk Cilacap Plant memiliki komitmen antara lain; 1) mengendalikan kualitas produksi di atas standar nasional; 2) mengutamakan keselamatan kerja; 3) mematuhi peraturan dan Undang-Undang yang berlaku; 4) tidak ada area bekas penambangan tanpa dilakukan reklamasi; 5) melakukan pemantauan dan pengelolaan lingkungan sesuai; dokumen AMDAL yng disetujui, bahkan di atas peraturan perundangan; 6) menjaga kelestarian sumber daya alam dan pemanfaatan limbah, 7) menjalin hubungan yang harmonis dengan semua (pemangku kepentingan) dan membuat laporan publik secara rutin; dan 8) menjalankan tanggung jawab sosial perusahaan guna meningkatkan kualitas hidup masyarakat sekitar.

Selain itu Triple Bottom Line adalah tiga hal yang mendasari operasional PT. Holcim Indonesia Tbk Cilacap Plant yaitu penciptaan nilai tambah (creating value added) untuk semua stakeholder, kinerja lingkungan yang berkelanjutan, serta tanggung jawab sosial adalah faktor yang saling berkaitan untuk menjamin keberlangsungan bisnis perusahaan.

Struktur implementasi program CSR PT. Holcim Indonesia Tbk Cilacap Plant bertujuan untuk membantu menemukan kompetensi inti Kabupaten Cilacap yang diawali dengan pemetaan sosial, merangkum aspirasi masyarakat dalam Forum Komunikasi Masyarakat (FKM), dan mengetahui kondisi kabupaten Cilacap secara keseluruhan (infrastruktur, ekonomi, pendidikan, kesehatan, dan sosial budaya ) serta mempertimbangkan tujuan umum pemerintah yaitu peningkatan IPM dan SDGs, sehingga pada akhirnya kemandirian masyarakat Kabupaten Cilacap akan tetap berkembang. Berikut bagan yang menjelaskan strategi dasar yang diterapkan PT. Holcim Indonesia Tbk Cilacap Plant dalam gambar 1. dibawah ini: 


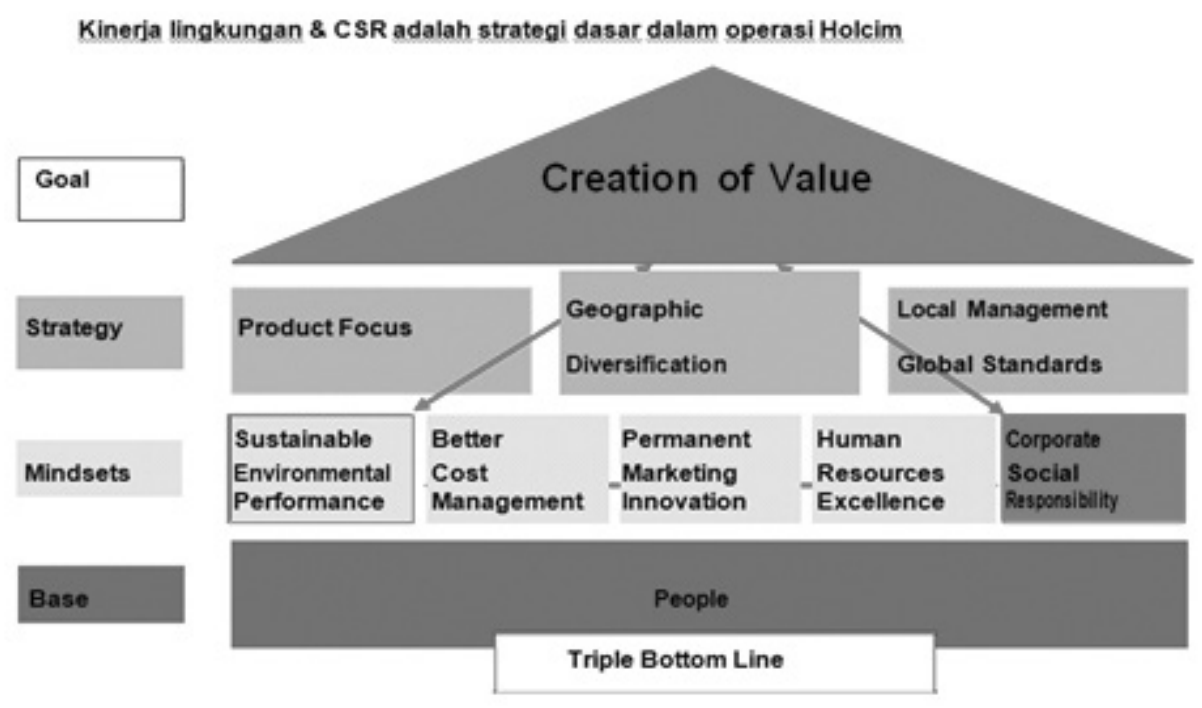

Gambar 1. Strategi Dasar Dalam Operasi Holcim

Sumber: Profil PT. Holcim Indonesia Tbk Cilacap Plant, 2015.

Berdasarkan gambar 1 dapat diketahui bahwa PT. Holcim Indonesia Tbk Cilacap Plant dalam menjalankan operasi bisnisnya untuk mindsets, strategy dan goal menggunakan kinerja lingkungan (Sustainable Environmental Performance) dan Corporate Social Responsibility (CSR) sebagai dasarnya. Berikut pernyataan yang disampaikan Bapak Kusdiarto selaku penanggung jawab program CSR PT. Holcim Indonesia Tbk Cilacap Plant mengemukakan:

"Holcim menyambut baik UU No 40 tahun 2007 sebagai dasar hukum pelaksanaan CSR, CSR sebagai komitmen bisnis berdasarkan prinsip Triple Bottom Line, yaitu menciptakan nilai tambah bagi para stakeholders, kinerja lingkungan yang berkelanjutan dan tanggung jawab sosial perusahaan. Artinya untuk memperoleh keuntungan (value) bagi shareholder maupun stakeholder, ada dua hal yang tidak boleh ditinggalkan yaitu kinerja lingkungan yang berkelanjutan dan tanggungjawab sosial perusahaan (CSR)”.

(Wawancara Bapak Kusdiharto GA \& ComRel Manager di Kantor PT. Holcim Tbk Cilacap Plant tanggal 2 Juni 2018).

Sampai saat ini PT. Holcim Indonesia Tbk Cilacap Plant sudah memiliki kebijakan CSR khusus yang digunakan sebagai pedoman dalam pelaksanaan program CSRnya yang sejalan dengan regulasi pemerintah.

Kebijakan Corporate Social Responsibility (CSR) ini bersifat mengikat kepada PT. Holcim Indonesia Tbk Cilacap Plant dan prinsip-prinsip kebijakan CSR ini juga harus diterapkan pada seluruh cabang PT. Holcim Indonesia dimana PT. Holcim Indonesia telah menanamkan sahamnya dalam yurisdiksi Republik Indonesia.

Program CSR PT. Holcim Indonesia Tbk Cilacap Plant berada pada Divisi Community Relation (Comrel). Adapun untuk pengkomunikasian program CSR kepada stakeholdernya menjadi tanggung jawab Corporate Communication. Berikut seperti yang disampaikan Deni Nuryandain selaku Corporate Communication Manager dalam wawancara berikut ini:

"Penanggungjawab program CSR adalah Divisi Community Relation (Comrel), kami membantu dan mensuport penuh dalam hal pengkomunikasian program CSR kepada seluruh stakeholder baik itu pemerintah, investor, pemasok, maupun masyarakat luas melalui berbagai media publikasi yang ada misalnya majalah internal, website, melalui media konvensional koran lokal misalnya Radar Banyumas, Satelit Post, TV dan Radio lokal serta media sosial yang kami miliki seperti Facebook"

(Wawancara Bapak Deni Nuryandain Corporate Communication Manager di Hotel Grand Zuhri Yogyakarta tanggal 14 Agustus 2018).

Dalam melaksanakan program kerjanya PT. Holcim Indonesia Tbk Cilacap Plant memiliki komitmen yaitu bekerja sebagai mitra bagi seluruh pihak-pihak yang berkepentingan bagi perusahaan untuk memperbaiki kualitas hidup bagi karyawan, keluarga dan masyarakat di sekeliling lokasi operasional perusahaan.

Dalam menjalankan kebijakan program CSR, PT. Holcim Indonesia Tbk Cilacap Plant memiliki visi dan misi pemberdayaan masyarakat. Adapun visi pemberdayaan masyarakatnya adalah mewujudkan masyarakat sejahtera mandiri melalui kemitraan yang harmonis antara perusahaan, pemerintah daerah dan Lembaga Swadaya Masyarakat (LSM). Sedangkan misi pemberdayaan masyarakat PT. Holcim Indonesia Tbk Cilacap Plant adalah mendorong kemandirian 
masyarakat dalam mengembangkan aset ekonomi sumber daya alam, kualitas daya manusia dan mengembangkan alam dan lingkungan.

Terdapat 4 (empat) pilar utama yang menjadi prinsip pengembangan/pemberdayaan masyarakat PT. Holcim Indonesia Tbk Cilacap Plant yaitu meliputi 4 pilar yaitu Pilar Ekonomi, Pilar Pendidikan, Pilar Kesehatan dan Pilar Lingkungan dan Sosial Budaya. Seperti yang disampaikan oleh Bapak Kusdhiarto dalam wawancara berikut ini:

\begin{abstract}
"Bahwa meningkatnya kemandirian masyarakat secara berkesinambungan melalui 4 (empat) pilar pemberdayaan masyarakat yaitu ekonomi, pendidikan, kesehatan dan lingkungan adalah prinsip Community Development yang dilakukan PT. Holcim Indonesia Tbk Cilacap Plant dan pelaksanaan program CSR sesuai visi misi kami " (Wawancara, Bapak Kusdiharto GA \& ComRel Manager di Kantor PT. Holcim Tbk Cilacap Plant tanggal 2 Juni 2018).
\end{abstract}

Dengan demikian kebijakan pemerintah tentang CSR telah diimplementasikan melalui kebijakan CSR PT. Holcim Indonesia Tbk Cilacap Plant melalui 6 (enam) pilar CSR dengan visi dan misi pemberdayaan masyarakat yang berfokus kepada pengembangan 4 (empat) pilar yaitu, ekonomi, pendidikan, kesehatan, dan lingkungan sosial budaya yang mengacu kepada sumberdaya alam dan kearifan lokal melalui kemitraan yang harmonis antara perusahaan, pemerintah daerah, masyarakat dan LSM serta perguruan tinggi.

\title{
e. Motif PT. Holcim Indonesia Tbk Cilacap Plant dalam Melaksanakan Program CSR
}

Dalam melaksanakan program CSR Kotler dan Lee (2005) mengidentifikasi terdapat enam (6) pilihan program bagi perusahaan untuk melakukan inisiatif dan aktivitas sebagai wujud komitmen dari tanggung jawab sosial perusahaan. Keenam pilihan sebagai motif perusahaan dalam melakukan CSR, yaitu: 1). Cause Promotions (Promosi Kegiatan Sosial), 2). Cause-Related Marketing (Pemasaran terkait kegiatan sosial), 3). Corporate Social Marketing (Pemasaran kemasyarakatan perusahaan), 4). Corporate Philantrophy (Kegiatan Filantropi perusahaan), 5). Community Volunteering (Pekerja sosial kemasyarakatan secara sukarela) dan 6). Socially Responsibility Bussiness Practices (Praktik bisnis yang memiliki tanggung jawab sosial).

PT. Holcim Indonesia Tbk Cilacap Plant dalam melaksanakan CSR tidak hanya melakukan kegiatan CSR yang sifatnya philantrophy, dengan memberikan bantuan saja yang bersifat sementara tidak berkelanjutan (sustainable). Akan tetapi dilakukan dengan motif Socially Responsibility Bussiness Practices sebagai bentuk praktik bisnis yang memiliki tanggung jawab sosial dimana perusahaan melaksanakan praktik bisnis dengan tetap bertanggungjawab secara sosial melalui capaity building dengan memberikan pelatihan dan pendampingan kepada masyarakat penerima program CSR.. Hal ini seperti yang disampaikan pada wawancara berikut ini:

PT. Holcim menjalankan CSR adalah sebagai komitmen bisnis bentuk tanggungjawab perusahaan secara sosial dan moral sekaligus berkontribusi dalam pembangunan melalui program pemberdayaan masyarakat kami memberikan capacity building melalui pelatihan dan pendamingan kepada masyarakat bukan uang tunai melalui pelatihan, psebagendampingan masyarakat dengan menyesuaikan potensi dan kebutuhan masyarakat. Sehingga masyarakat mandiri."

(Wawancara, Bapak Kusdiharto GA \& ComRel Manager di Kantor PT. Holcim Tbk Cilacap Plant tanggal 2 Juni 2018).

Hal ini dilakukan dengan cara memberikan dukungan dalam pengembangan masyarakat yang disesuaikan dengan usaha atau kegiatan bisnis yang dimiliki masyarakat, menyesuaikan potensi yang dimiliki masyarakat dan kebutuhan masyarakat. Untuk pengembangan masyarakatnya dilakukan pada berbagai bidang kehidupan diantaranya bidang ekonomi, pendidikan, kesehatan, lingkungan dan sosial budaya, komunitas dengan tujuan menciptakan visibilitas dan meningkatkan reputasi positif perusahaan di mata stakeholdersnya.

Adapun salah satu contoh program CSR PT. Holcim Indonesia Tbk Cilacap Plant adalah Bank Sampah Mandiri di Kelurahan Kebonmanis Cilacap. Program Bank Sampah Mandiri merupakan program pemberdayaan masyarakat yang diinisiasi oleh warga Kelurahan Kebonmanis dan dilaksanakan serta dievaluasi juga oleh masyarakat. Berdasarkan hasil penelitian, pemberdayaan masyarakat pada program CSR Bank Sampah Mandiri PT. Holcim Indonesia Tbk Cilacap Plant sampai saat ini masih sustainable karena pendekatan yang dipergunakan oleh perusahaan tidak semata-mata hanya melaksanakan program CSR seperti yang diregulasikan oleh pemerintah. Namun, PT. Holcim Indonesia Tbk Cilacap Plant menerapkan pendekatan pemberdayaan masyarakat yang memposisikan masyarakat sebagai subjek pemberdayaan bukan hanya objek. Dengan demikian perusahaan melakukan kolaborasi dan bersinergi dengan masyarakat agar masyarakat mempunyai rasa memiliki terhadap program pemberdayaan Bank Sampah Mandiri. Hal ini seperti yang disampaikan dalam wawancara berikut ini: 
"Program CSR Bank Sampah Mandiri sampai saat ini masih sustain bahkan berkembang pesat dengan adanya unit usaha baru seperti laundry, cucian motor dikarenakan Holcim memberikan penguatan kapasitas manusia melalui pelatihan dan pendampingan misalnya pelatihan pengelolaan sampah organik dan non organik, pelatihan kerajinan sampah, pelatihan manajemen dan keuangan kelompok, sehingga masyarakat Kebonmanis bisa mandiri meskipun sudah exit program".

(Wawancara, Bapak Kusdiharto GA \& ComRel Manager di Kantor PT. Holcim Tbk Cilacap Plant tanggal 2 Juni 2018).

Dalam menerapkan CSR menurut Suharto (2010) terdapat 3 (tiga) tipologi perusahaan dalam yaitu Perusahaan Nakal, Perusahaan Licik, Perusahaan Baik, dan Perusahaan Maju. Berdasarkan tipologi perusahaan dalam menerapkan CSR, PT. Holcim Tbk Indonesia Cilacap Plant khususnya pada program CSR Bank Sampah Mandiri termasuk perusahaan baik dikarenakan melakukan CSR berdasarkan kaidah-kaidah Community Development. Hal ini dilakukan dengan menyesuaikan potensi dan kebutuhan masyarakat penerima manfaatnya yakni potensi timbulnya masalah karena sampah dan kebutuhan akan pentingnya pengelolaan sampah rumah tangga serta kebutuhan masyarakat terutama ibuibu rumahtangga mendapatkan pekerjaan tambahan untuk meningkatkan ekonomi rumah tangga. Hal ini dapat terealisir dengan program CSR Bank Sampah Mandiri. Dalam hal ini sampah yang tidak berguna bisa ditabung ditukarkan menjadi kebutuhan pokok dan sampah un-organik yang masih bisa diolah dapat dijadikan kerajinan sampah sehingga memiliki nilai ekonomi.

\section{f. Deskripsi Pelaksanaan Program CSR Delegation Of The European Union To Malaysia}

Delegation of the European Union to Malaysia memiliki core bisnis menjalankan misi diplomatik Uni Eropa dan bertugas untuk mempromosikan hubungan yang lebih erat dengan Malaysia. Hal ini dilakukan dengan menyediakan saluran komunikasi yang efisien dan dapat diandalkan antara Uni Eropa dan otoritas Malaysia, bisnis, lembaga pendidikan dan masyarakat sipil juga mempromosikan kontak antar-orang dan menyoroti keragaman budaya dan bahasa Eropa. Selain itu juga mendukung pertukaran pendidikan tinggi Eropa dan memfasilitasi kerjasama di bidang sains dan teknologi melalui berbagai kegiatannya juga melaksanakan program CSR sebagai bentuk tanggungjawab sosialnya terhadap kegiatan bisnis yang dilakukan.

Tugas khusus Delegation of the European Union to Malaysia adalah sebagai berikut:1). Mewakili Uni Eropa dalam pelaksanaan kompetensinya, 2). Meningkatkan hubungan politik, ekonomi dan komersial bilateral, 3). Promosikan dan pertahankan nilai dan kepentingan Uni Eropa; dan 4). Mengejar kebijakan informasi dan komunikasi yang sejalan dengan strategi keseluruhan Uni Eropa di Asia Tenggara, 5). Delegasi Uni Eropa bekerja dalam hubungan dekat dengan Kedutaan Negara Anggota Uni Eropa yang ada di Malaysia dan mempromosikan posisi umum Uni Eropa dan kebijakan di bidang kompetensi UE. Dalam menjalankan operasi bisnisnya Delegation of the European Union to Malaysia menjalankan misi diplomatik Uni Eropa dan bertugas untuk mempromosikan hubungan yang lebih erat dengan Malaysia.

Adapun strategi pelaksanaan CSR Delegation of the European Union to Malaysia adalah mempromosikan pelaksanaan program CSR di Uni Eropa dan mendorong perusahaan untuk mematuhi pedoman dan prinsip internasional. Adapun kebijkan CSR dari Delegation of the European Union to Malaysia dibangun dengan tujuan untuk 1). Meningkatkan visibilitas CSR dan menyebarluaskan praktek bisnis yang baik, 2). Meningkatkan dan melacak tingkat kepercayaan dalam operasional bisnis, 3). Memperbaiki proses self dan co-regulation perusahaan, 4). Meningkatkan penghargaan pasar untuk CSR, 5). Meningkatkan kepedulian perusahaan terhadap ekonomi, sosial dan lingkungan, 6). Mengintegrasikan kebijakan CSR perusahaan dalam bidang pendidikan, kesehatan, sosial dan lingkungan. Berikut wawancara Dzul Affandi Matnoor selaku Press and Information Officer terkait pelaksanaan program CSR-nya :

"Bagi Delegation of the European Union to Malaysia melaksanakan CSR adalah bentuk tanggung jawab perusahaan atas dampak bisnis yang dilakukan kepada masyarakat. Selain itu CSR penting dilakukan untuk keberlanjutan perusahaan, meningkatkan daya saing perusahaan dan bermanfaat untuk manajemen resiko perusahaan, penghematan biaya operasiona, memperoleh akses modal yang luas, meningkatkan hubungan positif dengan pelanggan serta manajemen sumber daya manusia”. (Wawancara, Bapak Dzul Affandi Matnoor selaku Press and Information Officer tanggal 16 Juli 2018).

Dalam melaksanakan program CSR Delegation of the European Union to Malaysia tidak bekerja sendiri melainkan bermitra dengan pemerintah Malaysia dan perusahaan lain serta NGO di Malaysia yang bergerak di bidang kesehatan, pendidikan dan konservasi lingkungan.

Adapun divisi yang bertanggungjawab melaksanakan program CSR sekaligus mengkomunikasikan program CSR kepada seluruh stakeholdernya adalah Divisi Press and Information. Dalam hal ini tugas Press and Information pada program CSR dengan cara menyediakan saluran komunikasi yang efisien melalui media publikasi seperti media TV, Radio maupun sosial media yang dimiliki. Dengan demikian antara Uni Eropa dan otoritas Malaysia terjalin komunikasi 
dan kerjasama yang efektif baik di bidang bisnis, lembaga pendidikan dan masyarakat sipil sehingga kegiatan CSR dalam bidang pendidikan, ekonomi, sosial dan lingkungan yang dilakukan bersama perusahaan di Uni Eropa dapat berjalan sesuai yang direncanakan.

Tujuan dalam pelaksanaan program CSR bagi Delegation of the European Union to Malaysia adalah untuk menciptakan visibilitas dan meningkatkan citra perusahaan. Hal ini seperti yang disampaikan Dzul Affandi Matnoor selaku Press and Information Officer berikut ini:

"CSR bagi Delegation of the European Union to Malaysia penting dilakukan terutama untuk menciptakan visibilitas dan citra positif di mata stakeholder sehingga kami memiliki banyak klien yang mau bekerja sama dengan kami”

(Wawancara, Bapak Dzul Affandi Matnoor selaku Press and Information Officer tanggal 16 Juli 2018).

Adapun salah satu contoh program CSR unggulan Delegation Europian Union to Malaysia adalah program pengembangan Usaha Kecil dan Menengah (UKM) di negara berkembang. Hal ini sangat penting dilakukan untuk meningkatkan dampak bisnis di masyarakat dan menjadi bagian penting dari komitmen bisnis perusahaan untuk mendukung dan bertanggungjawab dalam peningkatan dampak sosial dan lingkungan sehingga dapat berjalan seiring dengan kualitas manajemen yang lebih baik melalui pemberian bantuan modal dan pelatihan terkait manajemen pengembangan usaha.

Adapun bentuk kegiatan program CSR yang dilakukan adalah melalui pemberian bantuan modal dan pelatihan yang sangat bermanfaat bagi wirausahawan kecil / UMKM. Berikut seperti yang disampaikan Bapak Dzul Affandi Matnoor selaku Press and Information Officer dalam wawancara berikut ini:

"Bentuk program CSR kami salah satunya melalui pemberian bantuan modal usaha serta berbagai pelatihan usaha yang dibutuhkan seperti pelatihan kewirausahaan, pelatihan keuangan dan pemasaran yang sangat dibutuhkan dalam pengembangan UMKM“".

(Wawancara, Bapak Dzul Affandi Matnoor selaku Press and Information Officer tanggal 16 Juli 2018).

Berdasarkan wawancara diatas pelaksanaan program CSR Delegation Europian Union to Malaysia dilakukan dengan meningkatkan kapasitas manusia berupa pemberian berbagai pelatihan usaha yang dibutuhkan serta peningkatan kapasitas usaha dengan pemberian modal usaha untuk pengembangan usaha yang dimiliki masyarakat yang menjadi penerima manfaat program CSR.

\section{g. Motif Delegation Of The European Union To Malaysia dalam Melaksanakan Program CSR}

Berdasarkan data yang ditemukan di lapangan oleh tim peneliti, bahwa Delegation Of The European Union To Malaysia dalam melaksanakan program CSR bukan hanya melaksanakan CSR yang sifatnya philantrophy, atau hanya memberikan bantuan saja yang bersifat sementara tidak berkelanjutan (sustainable). Akan tetapi motif dalam pelaksanaan program CSR yaitu Socially Responsibility Bussiness Practices (praktik bisnis yang memiliki tanggung jawab sosial) dimana perusahaan melaksanakan praktik bisnis dengan tetap bertanggungjawab secara sosial.

Hal ini dilakukan dengan cara memberikan dukungan dalam pengembangan masyarakat yang disesuaikan dengan usaha atau kegiatan bisnis yang dimiliki masyarakat, menyesuaikan potensi yang dimiliki masyarakat dan kebutuhan masyarakat. Untuk pengembangan masyarakatnya dilakukan pada berbagai bidang kehidupan diantaranya bidang ekonomi, pendidikan, kesehatan, lingkungan dan sosial budaya, komunitas dengan tujuan menciptakan visibilitas dan meningkatkan reputasi positif perusahaan di mata stakeholdersnya. Hal ini seperti yang disampaikan dalam wawancara Bapak Dzul Affandi Matnoor selaku Press and Information Officer berikut ini:

"Kami melakukan program CSR karena merupakan bentuk menjalankan praktik bisnis dengan tetap bertanggungjawab secara sosial. Hal ini dilakukan dengan cara memberikan dukungan dalam pengembangan masyarakat dengan menyesuaikan apa yang dibutuhkan masyarakat, baik dalam bidang ekonomi misalnya pengembangan UMKM, bidang pendidikan melalui pemberian beasiswa ataupun bidang konservasi lingkungan". Hal ini sangat berdampak pada reputasi Kami di mata stakeholder”.

(Wawancara, Bapak Dzul Affandi Matnoor selaku Press and Information Officer tanggal 16 Juli 2018).

Berdasarkan tipologi perusahaan dalam menerapkan CSR, khususnya pada program CSR Pengembangan UMKM. Delegation of the European Union to Malaysia adalah termasuk perusahaan baik dikarenakan melakukan CSR berdasarkan kaidah-kaidah Community Development. Dalam hal ini pada program CSR Pengembangan UMKM dilakukan dengan menyesuaikan potensi dan kebutuhan masyarakat penerima manfaatnya. Adapun potensi masyarakat adalah adanya usaha UMKM milik masyarakat yang siap untuk dikembangkan melalui peningkatan kapasitas manusia dan usaha. 
Hal ini dilakukan melalui beragam program pelatihan yang dapat dijadikan modal masyarakat untuk mengembangkan UMKM yang dimiliki seperti pelatihan manajemen usaha, manajemen keuangan dan pemasaran. Selain itu juga dengan memberikan bantuan peminjaman modal.

Berdasarkan pada wawancara informan serta data dokumen dari dua perusahaan yakni PT. Holcim Indonesia Tbk Cilacap Plant dan Delegation of the European Union to Malaysia bahwa pelaksanaan program CSR sangat dipengaruhi oleh visi, misi serta kebijakan CSR yang menjadi dasar dalam pelaksanaan aktivitas CSR. Selain itu juga kedua perusahaan ini sama-sama sepakat bahwa pelaksanaan program CSR adalah sebagai bentuk tanggungjawab sosial atas usaha bisnis yang dilakukan serta yang terpenting juga adalah sebagai sarana / tools menciptakan visibilitas dan meningkatkan citra positif perusahaan di mata seluruh stakeholdersnya dalam bidang peningkatan bidang kehidupan baik pendidikan, ekonomi, sosial dan lingkungan untuk mewujudkan kesejahteraan masyarakat.

Dalam melaksanakan program CSR Kotler dan Lee (2005) mengidentifikasi terdapat enam (6) pilihan program bagi perusahaan untuk melakukan inisiatif dan aktivitas sebagai wujud komitmen dari tanggung jawab sosial perusahaan. Keenam pilihan sebagai motif perusahaan dalam melakukan CSR, yaitu: 1). Cause Promotions (Promosi Kegiatan Sosial), 2). Cause-Related Marketing (Pemasaran terkait kegiatan sosial), 3). Corporate Social Marketing (Pemasaran kemasyarakatan perusahaan), 4). Corporate Philantrophy (Kegiatan Filantropi perusahaan), 5). Community Volunteering (Pekerja sosial kemasyarakatan secara sukarela) dan 6). Socially Responsibility Bussiness Practices (Praktik bisnis yang memiliki tanggung jawab sosial). Berdasarkan data yang ditemukan di lapangan oleh tim peneliti, bahwa kedua perusahaan ini sangat concern dalam melaksanakan program CSR bukan hanya melaksanakan CSR yang sifatnya philantrophy, memberikan bantuan saja yang bersifat sementara tidak berkelanjutan (sustainable) melainkan dengan motif Socially Responsibility Bussiness Practices (praktik bisnis yang memiliki tanggung jawab sosial) dimana perusahaan melaksanakan praktik bisnis dengan tetap bertanggungjawab secara sosial. Hal ini dilakukan dengan cara memberikan dukungan dalam pengembangan masyarakat yang disesuaikan dengan usaha atau kegiatan bisnis yang dimiliki masyarakat, menyesuaikan potensi yang dimiliki masyarakat dan kebutuhan masyarakat. Untuk pengembangan masyarakatnya dilakukan pada berbagai bidang kehidupan diantaranya bidang ekonomi, pendidikan, kesehatan, lingkungan dan sosial budaya, komunitas dengan tujuan menciptakan visibilitas dan meningkatkan reputasi positif perusahaan di mata stakeholdersnya.

Saat ini terutama di Indonesia dengan adanya kewajiban ber CSR karena berlakunya Undang-undang PT pasal 74 yang memuat tentang aturan tentang tanggung jawab social dan lingkungan dan berdasarkan Undang-undang Penanaman Modal No. 25 tahun 2007 pasal 15 dan 34 disebutkan bahwa perusahaan yang tidak melaksanakan CSR akan dikenakan sanksi administratif berupa peringatan tertulis, pembatalan kegiatan usaha, pembekuan kegiatan usaha, dan yang terkahir adalah pencabutan izin kegiatan usaha.

Dengan demikian untuk perusahaan di Indonesia saat ini sudah mulai berfokus pada CSR. Dengan demikian, tampaknya perusahaan mulai berpindah fokus dari pandangan sempit yang hanya bertujuan memaksimalkan laba saja, tetapi ke tujuan yang lebih luas yakni CSR yaitu juga berkontribusi positif untuk kehidupan sosial, ekonomi dan lingkungan (Kolstad, 2007). Hal ini juga di lakukan oleh perusahaan di Malaysia. Menurut penelitian yang dilakukan Ivan Kolstad (2007), “appeareance can, however, be deceiving” bahwa ternyata kebanyakan perusahaan memandang CSR lebih sebagai alat untuk meningkatkan profitabilitas saja daripada sebagai tujuan CSR itu sendiri. Dengan demikian dalam hal ini motif perusahaan dalam melaksanakan CSR bukan hanya phylantrophi semata melainkan motif Socially Responsibility Bussness Practices yakni praktik bisnis yang memiliki tanggung jawab sosial dengan cara memberikan dukungan dalam pengembangan masyarakat yang disesuaikan dengan usaha atau kegiatan bisnis masyarakat untuk membantu kesejahteraan masyarakat.

Motif perusahaan dalam melaksanakan CSR pada PT Holcim Indonesia Tbk Cilacap Plant Indonesia dan Delegation Europian Union to Malaysia di Malaysia memperkuat teori yang disampaikan Freeman dalam Becchetti \& Ciciretti ( 2006) dengan teori stakeholder-nya bahwa perilaku memaksimalkan laba diperkenankan dalam konteks memaksimalkan kesejahteraan masyarakat, dimana perusahaan dapat menetapkan peraturan dan memberikan insentif fiskal agar individu dan sosial dapat mencapai kesejahteraan maksimal.

Selain itu, Freeman juga menyatakan bahwa CSR merupakan strategi optimal untuk meminimalkan agency costs dengan para stakeholdernya. Freeman dalam hal ini mendukung gagasan bahwa CSR penting untuk kelangsungan perusahaan dalam jangka panjang, karena CSR tidak hanya memaksimalkan shareholder return, namun memenuhi semua keinginan stakeholder secara seimbang dan berkesinambungan dalam jangka panjang.

Dalam hal ini pada konteks jangka panjang, CSR juga dapat membuat stakeholder merasa diperhatikan oleh perusahaan sehingga mereka bersimpati pada perusahaan, sehingga dapat meminimalkan konfrontasi dari para stakeholdernya. CSR juga dapat berdampak pada pembentukan citra positif perusahaan sehingga perusahaan dapat meningkatkan penjualan dan laba dalam jangka panjang. Saat ini tuntutan dari stakeholder, perusahaan melakukan CSR dan kemudian melaporkan kegiatan CSR berdampak pada pelanggan yang makin loyal, calon investor akan dengan senang hati menanamkan modal, kreditor dan pemasok akan dengan senang hati bekerjasama dengan perusahaan, dan para pemerhati lingkungan akan mendukung serta masyarakat sekitar perusahaan juga akan senang dengan kehadiran perusahaan karena kontribusinya terhadap kehidupan ekonomi, sosial dan lingkungan. 
Selain itu berdasarkan temuan, jika menurut Suharto (2010) terdapat 3 (tiga) tipologi perusahaan dalam menerapkan CSR yaitu Perusahaan Nakal, Perusahaan Licik, Perusahaan Baik, dan Perusahaan Maju. Berdasarkan tipologi perusahaan dalam menerapkan CSR, PT. Holcim Tbk Indonesia Cilacap Plant khususnya pada program CSR Bank Sampah Mandiri dan Delegation Europian Union to Malaysia pada program pengembangan UMKM keduanya termasuk perusahaan baik dikarenakan melakukan CSR berdasarkan kaidah-kaidah Community Development yaitu mengembangkan masyarakat yang dilakukan dengan memberikan capacity building melalui pelatihan, pendampingan dan pemberian bantuan modal usaha secara bertanggungjawab. Artinya perusahaan tidak hanya memberikan bantuan modal saja tanpa pendampingan secara berkelanjutan sehingga masyarakat dapat mandiri. Pada saat program CSR telah berakhir (exit program), masyarakat tetap dapat menjalankan keberlanjutan program CSR. Dalam hal ini dibutuhkan komunikasi dan kerjasama secara berkelanjutan antara perusahaan dan masyarakat penerima manfaat program CSR sehingga masyarakat tetap bersemangat melanjutkan sustainability program. Hal ini menjadi penting agar program CSR benar-benar dapat dirasakan manfaatnya dan mampu membantu peran pemerintah dalam peningkatan kesejahteraan masyarakat.

\section{KESIMPULAN}

Perusahaan dalam melaksanakan CSR memiliki motif yang berbeda beda. Ada yang melaksanakan CSR dengan motif phylantrophy/kedermawanan saja. Ada juga yang melaksanakan CSR hanya bermotif untuk melaksanakan peraturan saja karena CSR merupakan hal yang sifatnya mandatory. Ada pula perusahaan dalam melaksanakan CSR bermotif ekonomi saja/profit, yang tujuan akhirnya adalah untuk meningkatkan laba perusahaan. Namun dalam perkembangannya saat ini adanya tuntutan cerdas dari stakeholder, sudah banyak perusahaan yang melaksanakan program CSR dengan motif yang lebih dan lebih mulia khususnya pada PT Holcim Indonesia Tbk Cilacap Plant dan Delegation of the European Union to Malaysia di Malaysia yakni untuk meningkatkan kesejahteraan masyarakat dan untuk menjaga kelangsungan perusahaan dalam jangka panjang, sekaligus memperoleh laba yang signifikan. Hal ini dilakukan CSR dengan motif Socially Responsibility Bussiness Practices (praktik bisnis yang memiliki tanggung jawab sosial) dimana perusahaan melaksanakan praktik bisnis dengan tetap bertanggungjawab secara sosial. dengan cara memberikan capacity building melalui pelatihan, pendampingan dan pemberian modal usaha yang disesuaikan dengan kebutuhan masyarakat dan potensi yang dimiliki masyarakat. Adapun pengembangan masyarakatnya (community development) dilakukan pada berbagai bidang kehidupan diantaranya bidang ekonomi, pendidikan, kesehatan, dan lingkungan sebagai upaya mewujudkan kesejahteraan masyarakat serta menciptakan visibilitas dan meningkatkan reputasi positif perusahaan di mata stakeholdernya.

Dalam menerapkan CSR, PT. Holcim Tbk Indonesia Cilacap Plant maupun Delegation of the European Union to Malaysia termasuk perusahaan baik dikarenakan melakukan CSR berdasarkan kaidah-kaidah Community Development. Hal ini dilakukan dengan menyesuaikan potensi dan kebutuhan masyarakat penerima manfaatnya.

Pada PT Holcim Indonesia Tbk Cilacap Plant sebagai penanggung jawab pelaksana program CSR adalah Divisi Community Relation dan untuk pengkomunikasian program CSR oleh Divisi Corporate Communication melalui media publikasi yang ada seperti website, Face book, majalah internal dan media konvensional seperti liputan di media cetak koran dan media elektronik seperti radio lokal dan TV lokal. Sedangkan pada Delegation of the European Union to Malaysia yang menjadi penanggung jawab program CSR dan pengkomunikasian program CSR adalah Divisi Press and Information. Dalam hal ini tugas Press and Information pada program CSR dengan cara menyediakan saluran komunikasi yang efisien dan dapat diandalkan antara Uni Eropa dan otoritas Malaysia baik di bidang bisnis, lembaga pendidikan dan masyarakat sipil sehingga kegiatan CSR dalam bidang pendidikan, ekonomi, sosial dan lingkungan yang dilakukan bersama perusahaan di Uni Eropa dapat berjalan sesuai yang direncanakan.

Pada program CSR PT. Holcim Indonesia Tbk Cilacap Plant maupun Delegation of the European Union to Malaysia agar tercapai keberhasilan program CSR yakni terwujudnya kesejahteraan masyarakat diperlukan komunikasi dan kerjasama berkesinambungan antar perusahaan dengan masyarakat penerima manfaat program meskipun program CSR sudah exit program. Hal ini dilakukan agar masyarakat penerima manfaat program CSR bisa mandiri dan selalu bersemangat melanjutkan sustainability program.

\section{DAFTAR PUSTAKA}

Aguilera, Ruth V., Deborah E. Rupp, Cynthia A. Williams, and Jyoti Ganapathi. 2007. Putting The S Back in Corporate Social Responsibility: A Multilevel Theory of Social Change in Organizations. Academy of Management Review, Vol. 32, No. 3: pp. $836-863$.

Astono, Banu \& Hamzirwan, 2008, Semua Berawal dari CSR, Kompas, Jum’at, 25 April: pp. 47

Antonio Tencati, Francesco Perrini and Stefano Pogutz, 2004. New Tools to Foster Corporate Socially Responsible 
Behavior, Journal of Business Ethics, Vol. 53, No. 1/2, Building Ethical Institutions for Business: Sixteenth Annual Conference of the European Business Ethics Network (EBEN) pp.173-190

Amita V. Joseph, 2009. Successful Examples of Corporate Social Responsibility Indian Journal of Industrial Relations, Vol. 44, No. 3, Corporate Social Responsibility pp. 402-409

Becchetti, Leonardo \& Rocco Ciciretti, 2006. Corporate Social Responsibility and Stock Market Performance, Working Paper, CEIS Tor Vergata - Research Paper Series, Vol. 27, No. 79, March : pp. 1 - 30

Chand, Masud, 2007, The Relationship between Corporate Social Performance and Corporate Financial Performance: Industry Type as a Boundary Condition, The Business Review, Cambridge, Vol. 5, No. 1 (September): pp. 240 245

Cresswell, J.W. 2009.Research Design: Pendekatan Kualitatif, Kuantitatif and Mixed.EdisiKetiga. Yogyakarta: Pustaka Pelajar.

Ife, Jim. 2002. Community Development: Community Based Alternatives In An Age Of Globalisation, Pearson. Education Australia, Limited Australia.

Kolstad, Ivar, 2007, Why Firms Should Not Always Maximize Profits, Journal of Business Ethics, Vol. 76: pp. 137 - 145

Kotler, P dan N. Lee. 2005. Corporate Social Responsibility, Doing the Most Good for Your Company and Your Cause. New Jersey: Jhon Wiley \& Sons, Inc.

Mackey, Alison, Tyson B. Mackey, and Jay B. Barney, 2007, Corporate Social Responsibility and Firm Performance: Investor Preferences and Corporate Strategies, Academy of Management Review, Vol. 32, No. 3: pp. 817 - 835

Miles, M.B \& Huberman, A.M 1984, Qualitative Data Analysis : A Sourcebook of New Methods, London: Sage Publications.

Rudito,Bambang, \& Melia F, 2013.CSR Bandung:Rekayasa Sains

Sholeh, Arif. 2010. Peran Tanggungjawab Sosial Perusahaan Pertambangan Emas Agricount Resources Dalam Upaya Pemberdayaan Masyarakat Batangtoru Tapanuli Selatan. Disertasi.

Suharto, Edi. 2010 Membangun Mayarakat, Memberdayakan Mayarakat, Bandung Rafika Aditama.

Sutopo, HB. 2006. Metodologi Penelitian Kualitatif Dasar Teori dan Terapannya Dalam Penelitian, Surakarta: Universitas Sebelas Maret 